せに対しても，端末装置加らセンタ一装置に照会のうえ 回答できる，そのほか，回線運用時間や料金などの運用 資料を集計することも可能である.

本方式の導入により, 従来の手動操作のうち, 機械化 される作業をまとめると，(1)テレビ回線の割当処理, (2) 回線の接続切替作業, (3) 専用者別, 契約別回線使 用時間集計など，運用上必要な資料の作成，である．近 い将来には，伝送路障害時に緊急に迂回ルートを作成す る作業も機械化される計画である.

\section{〔参考 文 献〕}

1）川船，松本，林，橋谷，高椋：テレビジョン中継に㧍ける映音同 時伝送の全国導入，施設，23，7 (1971)

2）石川，大田：十滕沖地震を契機とする災害対策について，施設， 21, 3 (1969)

3）青江, 池部, 秦, 小川：12 MHz 同軸方式に扔ける VSB-TV 伝 送化, 施設, 22, 1 (1970)

4) 森下, 小堀, 寿司: C-60 M テレビジョン伝送方式の設計, 研実 報, 20,5 (1971)

5) 池部，江尻：CP-2-Tr 形同軸ビデオ方式，施設，23，6（1971)

6) 山根：本土・沖縄間マイクロ回線工事の概要, 施設, 23, 11(1971)

7) 滰本, 碓井, 古田, 酒井: テレビ回線制御システム (MASCOT) (その 1 ), 施設, 23，8 (1971)

8) 滰本, 碓井, 柴田：テレビ回線制御システム(その2)，施設， 23 , 9 (1971)

9) 滰本, 碓井, 戸上, 大滰, 安藤, 金島: テレビ回線制御システム (MASCOT) (その 3 ), 施設, 23, 10 (1971)

UDC 621.396.946: 621.397.743(100)

621. 396. 65

\title{
特 集テレビジョン年報
}

\section{国 際 中 継 技 術}

\section{1. ま がき}

テレビの国際中継は，INTELSAT-III 号系衛星によ って確立された世界衛星通信網を用いて, この 2 年間に 順調な発展をとげるとともに回線需要す安定してきた. 回線利用も多岐にわたり，昨今 “テレビ外交”なる新語 を生むに至った．乙の衛星通信発展の基礎となっている 国際商業衛星通信機構 (INTELSAT) は, 1964 年 8 月 20 日発足以来, 暫定制度のもとに運営されてきたが, 1972 年末頃には恒久制度に置き換えられる見込みであ る.

地球局および国際テレビセンター (ITC) の設備面の拡 充, 特に 1 個の衛星によるテレビ同時 2 伝送システムの 完成により, 国際テレビ回線の適応性は著しく增した。 また, non-fixed-ratio の変換が可能なテレビ標準方式変 換装置の完成により，ヨーロッパ諸国のように，わが国 とは異種の標準方式を採用している国々との実時間伝送 に扔ける番組交換が容易に行なえるようになった。

1970 年に入り, 新しい INTELSAT-IV 号系衛星に アクセスするための地球局の整備が各国で開始された. わが国は, 1971 年 8 月末, 茨城衛星通信所に第 3 施設を 建設し，太平洋上に打上げられた IV 号 $(\mathrm{F}-4)$ 衛星を用

"International Television Transmission Techniques" by Hideo Sato (KDD Co., Ltd., Tokyo)
国際電信電話株式会社佐藤秀夫

いた運用が行なわれている。

以上に述べた INTELSAT の衛星系とは別に、ヨー ロッパの EUROVISION 網, 東欧の INTERVISION 網，ソ連の国内通信のために開発された MOLNYA-1 号系衛星による ORBITA 網などの国際テレビ回線もさ らに充実された、また，ソ連を中心とする社会主義 9 力 国が，国際宇宙通信機構 (INTERSPUTNIK) 設立に関 する協定に署名した。

放送衛星については, 各国で寒用化のための努力が払 われ，CCIR でも積極的任研究が進められている，また 1971 年 $6 〜 7$ 月に開加た宇宙通信に関する世界無線 主管庁会議（WARC-ST）に括いて，技術基準の審議と とすに固定衛星業務抢よび放送衛星業務に対する周波数 の分配が行なわれた。

実験衛星計画のうち, わが国が参加している応用技術 衛星 (ATS) による実験では, 鹿島地球局の通信可能範 国に㐫るATS-1 号衛星を用いてテレビ伝送を含む各種 の通信実験が行なわれた。

以下，1970１972 年初期に拈けるテレビ国際中継技 術, 特に今日の国際テレビ伝送の普及を可能にした衛星 通信㧍よび関連技術を中心に述べる.

\section{2. 国際テレビ回線}

\section{1 回線構成}


今日，商業ベースで使用される国際テレビ回線の代表 的なあのとして，ヨーロッパ执よび北アフリカ諸国によ り構成される EUROVISION 網, 東ヨーロッパ諸国を 結ぶ INTERVISION 網，および INTELSAT が有す る世界衛星通信網があげられる，乙れらの網により構成 される実際の国際テレビ回線は，端末で国内回線区閒に 延長されたり，複数の網が相互に接続されたりして，さ らには標準方式変換装置が用いられるなど, 複雑化して きている.

現用されている回線構成は，次に示すように大別され $3^{1) \sim 3)}$.

（1）地上のケーブル，無線，あるいはケーブルと哭 線のリンクで構成される国際テレビ回線.

（2） 1 国際 (衛星) 回線区間と 2 国内回線区間で構 成される国際テレビ回線.

（3）（1）および(2)の国際テレビ回線を縦続接続し て構成される国際テレビリンク.

（4）（2）の国際テレビ回線を 2 段縦続接続して構成 される国際テレビリンク.

（5）上記の国際テレビ回線あるいはリンクに標準方 式変換装置を含む回線構成.

\subsection{CCIR および CCITT における研究}

2.1 節で述べたように, 複雑かつ長距離化してきた国 際テレビ回線に対好するため，テレビ伝送に関する国際 無線通信諮問委員会 (CCIR) と国際電信電話諮問委員会 (CCITT) の合同研究委員会 (CMTT) は, $2,500 \mathrm{~km}$ 標 準擬似回線とは別の“テレビ標準擬似チェーン”の研究 を開始し，第 12 回 CCIR 総会（1970 年1月～2月二 ユーデリーにて開催）で新しいレポートを作成した4). この他の主要審議事項としては, 国際接続用テレビ（力 ラー）回線の伝送規格, VITS の波形および挿入位置, 高品質モノフォニックおよびステレオフォニック伝送路 のための回線規格などがあげられる5).

一方, CCITT は研究委員会 IV (回線保守) で地上 执よび衛星回線区間で構成される国際テレビ回線の保守 そついて審議を行ない, カラーテレビ信号の伝送を考慮 した試験項目, 試験波形, 回線規格, 試験周期などに関 するとれまでのNシリーズ衔告を改訂する作業を続けて いる6).

なお，テレビ標準方式ごとに異なる雑音評洒特性につ いては，統一する方向で研究7) がなされ，525 ライン方 式のための VITS に関するコメント ${ }^{8}$ および時分割多重 方式による音声执よび画信号の伝送方式の提案 ${ }^{9}$ ととも に, 1972 年 7 月に開催される CCIR 中間会議に寄与文 書として提出されるととになった.

\subsection{INTELSAT 衛星と回線品質}

$560(46)$
1965 年 4 月に, 大西洋上に INTELSAT-I 号系衛星 (アーリーバード)が打上げられ，欧米間の商業通信が開 始された. その後, II 号系衛星（1966 年～1968 年）を 経て，1969年には III 号系衛星が打上げられ，世界衛星 通信網の完成をみた。さらに，1971年1月にはIII 号系 衛星の 5 倍の通信容量をむつIV 号系衛星][IV 号 $(\mathrm{F}-2)]$ が打上げられた. 大西洋上の第 $2 \mathrm{IV}$ 号衛星 (F-3) に引 き続き，1972 年 1 月 23 日太平洋上に IV 号 $(F-4)$ が打 上げられ，2月 14 日にこれまで使用していたIII号 (F-4) からIV 号衛星にポイントオーバーされた.

表1は INTELSAT-III および IV 号系衛星の主な諸 元を示すむのである ${ }^{10)}$. IV 号系衛星の特徴のひとつと して, 衛星通信に割り当てられた $500 \mathrm{MHz}$ の周波数帯 域幅を $36 \mathrm{MHz}$ 帯域幅の 12 個のトランスポンダーでカ バーしていることがあげられる. ての結果, III 号系の トランスポンダーにくらべ, 混変調雑音の軽減, 実効送 信電力の増加などの改善がなされた.

現在, 国際通信に使用されているINTELSAT 衛星は III 号系が 2 個（インド洋，太平洋上に各 1 個と）IV 号 系 3 個（太平洋上に 1 個, 大西洋上に 2 個）の合計 5 個 で，乙の他に III 号衛星が予備として配置されている. INTELSAT 加盟 81 力国中, 39 力国が 52 の地球局に 63 のアンテナ設備を置き(1971 年 12 月末現在), 乙れ らの衛星を利用して各種の通信を行なっている.

わが国は KDD 茨城, 山口両地球局により, 太平洋地 域の 8 力国 11 対地およびインド洋地域 9 力国 9 対地と 衛星中継テレビ回線を設定している.

INTELSAT-III および IV 号衛星を用いた衛星回線 区間のテレビ伝送のための諸元ならびに回線特性 ${ }^{11) 3)}$ 表 2 に示す.

\section{3. 国際テレビ中継業務}

\section{1 概 況}

1966 年 12 月, わが国は INTELSAT-II 号系衛星を経 由し，茨城局による国際テレビ中継業務を開始した。 そ れ以来今日までのわが国における四半期でとの国際テレ ビ回線の利用状況を図1 に示す ${ }^{-12)}$. 1970～1971 年の業 務内容は，メキシコオリンピック (1968年第 4 四半期) や アポロ中継(1969年第3 四半期)にみられるような大きな ピークはないが, 順調な推移をたどっているといえよう.

この 2 年間における中継業務の主要なむのとして, 日 本万国博覧会 (EXPO '70) 関係の番組中継 ${ }^{13)}$, 第 6 回 アジア競技大会の中継 ${ }^{14)}$, 国際電気通信 100 年記念行事 の一環として行なわれた中継 ${ }^{15)}$, 沖縄返還協定調印式の 日米同時伝送による中継 ${ }^{15)}$, 天皇・皇后両陛下の訪欧に 伴う中継などがあげられる. 国際電気通信 100 年記念の 
表 1 INTELSAT-III および IV 号衛星の諸元

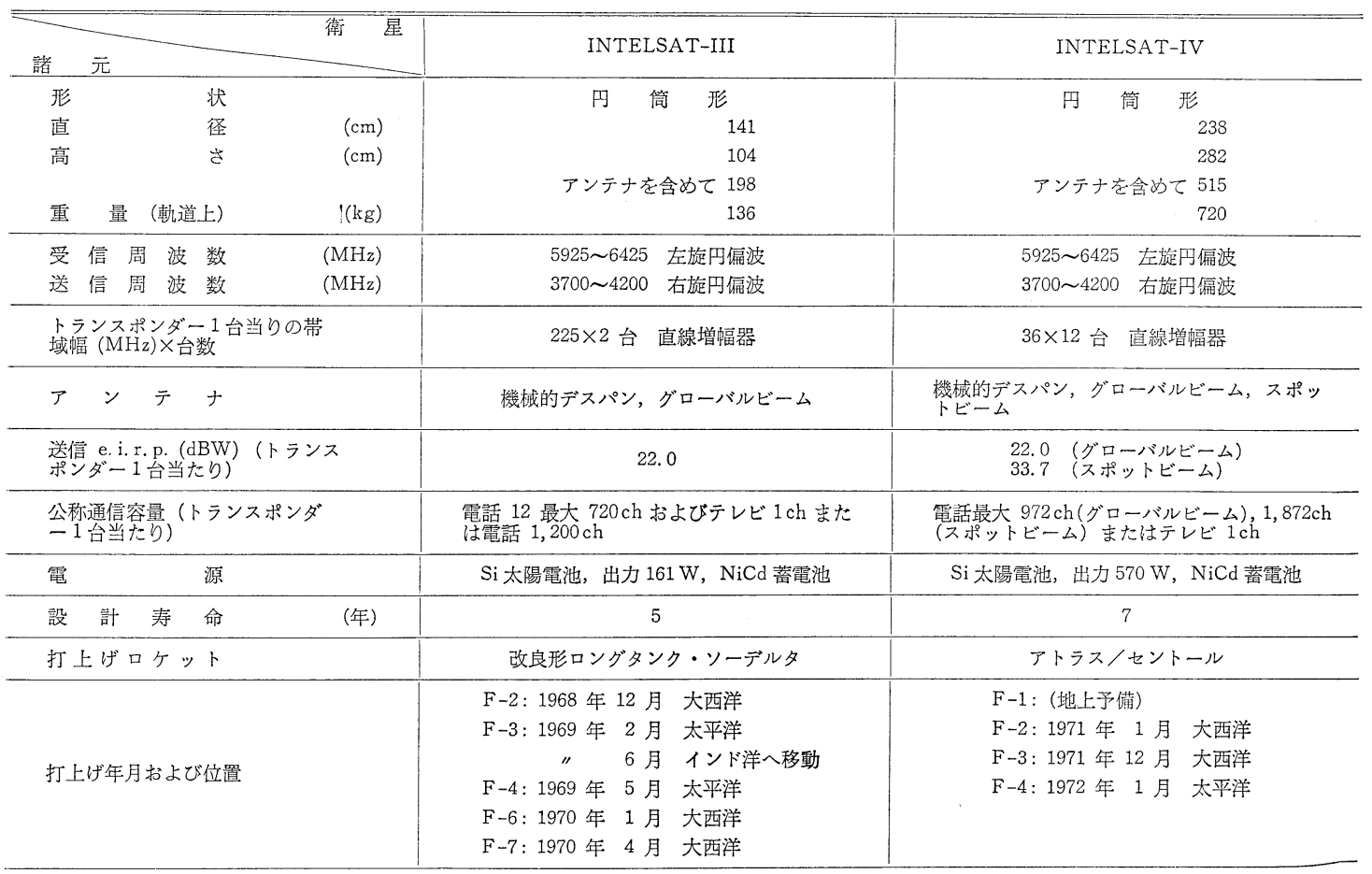

表 2 INTELSAT-III および IV 号系衛星によるテレビ伝送諸元

\begin{tabular}{|c|c|c|c|c|}
\hline \multirow{2}{*}{ 項 } & \multicolumn{2}{|r|}{ 衛 } & \multicolumn{2}{|l|}{ 系 } \\
\hline & \multicolumn{2}{|c|}{ INTELSAT-III } & \multicolumn{2}{|c|}{ INTELSAT-IV } \\
\hline 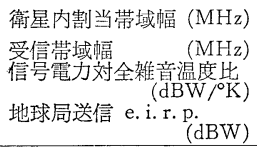 & \multicolumn{2}{|c|}{$\begin{array}{r}40 \\
25 \\
-142.0 \\
87.2 \\
\end{array}$} & & $\begin{array}{l}30 \\
30 \\
37.6 \\
88.0\end{array}$ \\
\hline テレビ標準方式 & $525 / 60$ & $625 / 50$ & $525 / 60$ & $625 / 50$ \\
\hline 最高映像伝送周波数 & 4.2 & 6 & 4.2 & 6 \\
\hline 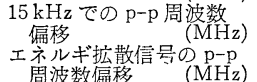 & $\begin{array}{l}7.5 \\
2\end{array}$ & $\begin{array}{l}5.8 \\
2\end{array}$ & $\begin{array}{l}6.8 \\
1\end{array}$ & $\begin{array}{l}5.1 \\
1\end{array}$ \\
\hline 信号効連続ランダム雑音 & 50 & 52 & 54 & 54 \\
\hline フィールド時間波形ひず (\%) & \pm 2 & \pm 2 & \pm 1 & \pm 1 \\
\hline ライン時間波形ひずみ & \pm 1.5 & \pm 1.5 & \pm 1 & \pm 1 \\
\hline 短時間波形ひずみ（\%) & 4 & 4 & 2 & 2 \\
\hline 微分利得 & 10 & 10 & 10 & 10 \\
\hline 微分位相 & 5 & 5 & & \\
\hline 振幅対周波数特性 (dB) & $\begin{array}{l}f_{c} * \text { で }+0.5 \\
-1.0\end{array}$ & $\begin{array}{l}f_{c}^{*} \text { で }{ }_{-1.0}^{+0.5} \\
\text {. }\end{array}$ & $f_{c}^{*}$ でー-1.0 & $f_{c}^{*}$ で_0.5 \\
\hline $\begin{array}{l}\text { エンベロープ遅延時間対 } \\
\text { 周波数特性 }\end{array}$ & \pm 75 & \pm 75 & \pm 50 & \pm 50 \\
\hline
\end{tabular}

\section{*: 最高映像伝送周波数}

テレビ伝送 “Children of the world” は，国際電気通信 連合 (ITU) が主催したWARC-ST，世界電気通信展 (TELECOM '71) 怙よび国際児童救済基金 (UNICEF) の創立 25 周年を記念して企画されたもので, 太平洋上 のINTELSAT-III 号 (F-4)，インド洋上の III 号 (F-3) 大西洋上の III 号(F-7) および IV 号(F-2) を用いて,

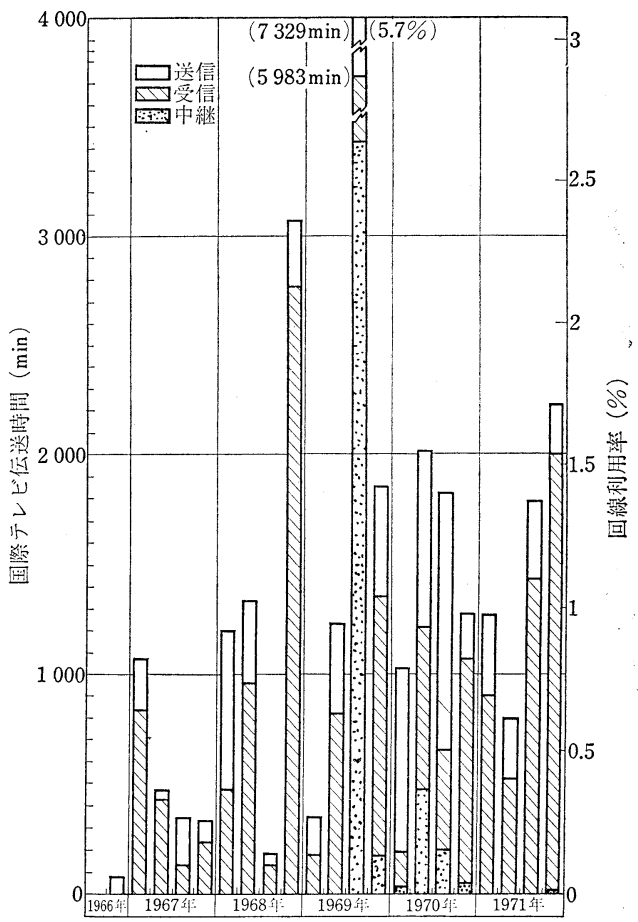

図 1 わが国の国際テレビ回線利用状況（各四半期）

11力国の放送局の共同制作による大掛りなむので，乙の ため, INTELSAT は衛星回線を無料で提供した. さら 


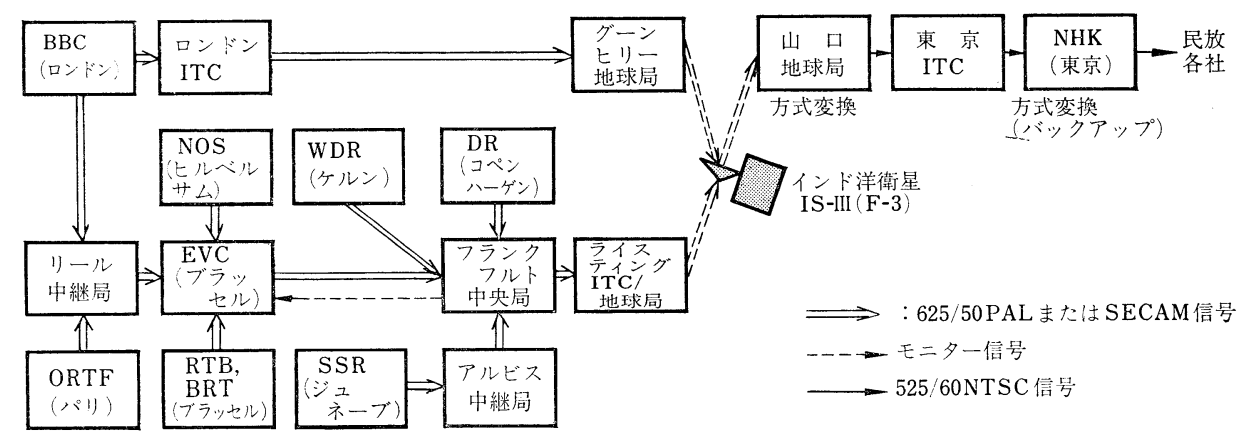

図 2 ヨーロッパ各国からの国際テレビ回線の構成(プール番組)

に記念行事の一環として, 日本一ハワイ間で初の大陸間 テレビ電話のデモンストレーションを行なった ${ }^{16)}$.また, ほぼ同時期に $3 \mathrm{kHz}$ バンドの専用回線を用いて音声と交 互にテレビタイプの画像情報を送受する“ビデオボイス” の公開実験が, ニニーヨークー東京間で行なわれた ${ }^{17)}$.

これらの記念行事を伝送するため, 太平洋衛星経由で テレビの同時 2 伝送ができるよう地球局の設備が拡充さ れた. その結果, 1971 年 6 月 17 日に行なわれた日米同 時テレビ衛星中継による“沖縄返還協定調印式” の伝送 が技術的に可能になった.

1972 年 2 月には, 第 11 回冬期オリンピック札幌大会 の中継と, ニクソン米大統領の中国訪問関係の中継があ った. 特に, 中国からの初の衛星中継には, 米国が INTELSAT 未加盟の中国に小形の移動用地球局を持ち込 み，太平洋上の IV 号 $(\mathrm{F}-4)$ を経由してテレビ番組を一 度ニコーヨークに伝送し，ここから全世界に分配した。

\section{2 天皇・皇后両陛下訪欧関係テレビ中継 ${ }^{18)}$}

1971 年秋の天皇・皇后画陛下の訪欧に関連したテレビ 中絉は，アンカレッジおよびヨーロッパ諸国から衛星回 線とEUROVISION 網を利用して日本へ送られてきた.
伝送時間は各テレビ局の共同取材によるプール番組と, 各局独自のユニラティラル番組を合わせると，34 伝送/ $1666 \mathrm{~min}(27 \mathrm{hr} 46 \mathrm{~min})$ に及んだ. 一例として，ヨーロ ッパ各国からインド洋衛星経由でプール番組を伝送した ときの回線構成を図 2 亿示す.

625 ライン PAL あるいは SECAM 方式から 525 ラ イン NTSC 方式への変換は, 山口地球局の変換装置を 用いて行ない, NHK の装置をバックアップ用として使 用した。

図 2 の回線構成の他に,インド洋衛星経由ではテレビ 伝送路が 1 回線しか設定できないため, プール番組の伝 送と同時間に行なわれたユニラティラル番組の伝送は, 大西洋㧤よび太平洋衛星経由の 2 ホップ回線で奏施され た.

\section{3 冬期オリンピック札幌大会の中継}

本大会の取材には 27 の外国テレビ関係機関が参加し 生あるいは編集された番組は茨城地球局から太平洋衛星 およびジェームスバーグ地球局経由で NBC と CBC の ネットワークに, 山口地球局からインド洋衛星およびブ イトラゴ地球局経由でョーロッパ放送連盟 (EBU) のネ
図 3 冬期オリンピック札幌大会 の国際テレビ中継回線の構成

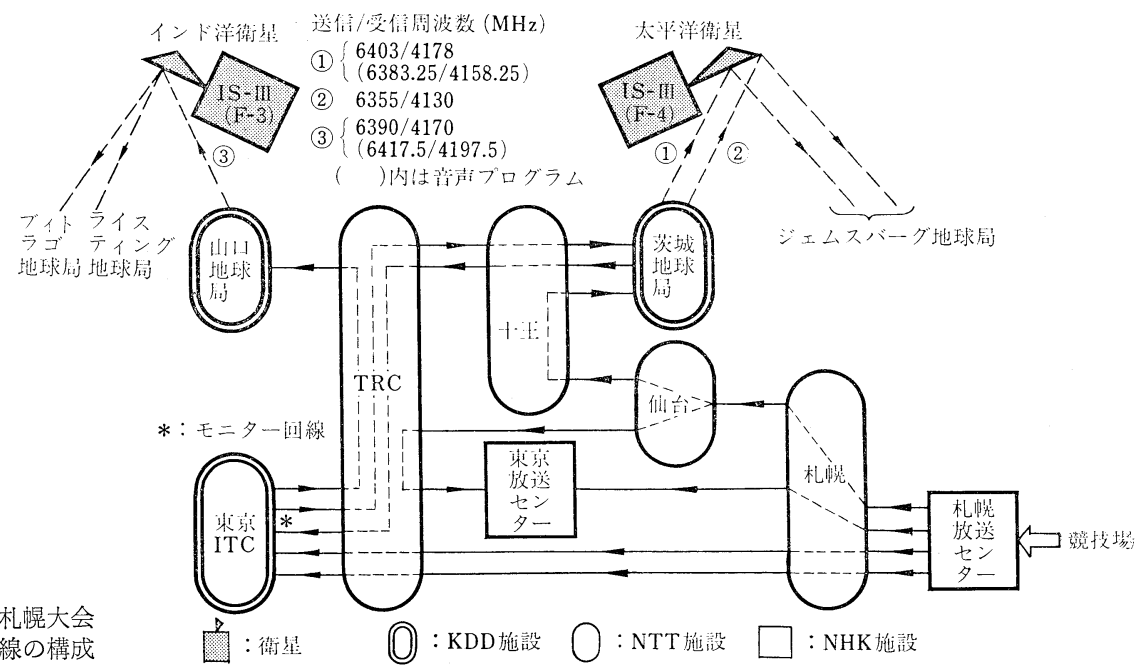


ットワークに，さらにライスティング地球局経由で国際 放送機構 (OIRT) のネットワークにそれぞれ伝送され, 各国のテレビ放送に使用された ${ }^{199}$.

上記の伝送を行なうため, 茨城地球局からジェームス バーグ地球局に向けて同時に映像用搬送波を 2 波送信し た. 山口地球局は 1 波のみ送信し，ブイトラゴおよびラ イスティング地球局は時分割で受信した.したがって, わが国からは同時に最大 3 つのテレビ番組が世界各国に 向けて中継されたわけで，その中継時間は約 2 週間の才 リンピック期間中に 103 伝送/10,084 min (168hr $4 \mathrm{~min}$ ) に及ぶ，てれまでの最高記録を作った。

図 3 亿冬期オリンピック札幌大会のテレビ伝送回線の 構成を示す。

\section{4. 国際テレビ中継設備}

\section{1 衛星回線のテレビ伝送標準と地球局設備}

INTELSAT の運営を管理する, 通信衛星暫定委員会 (ICSC) は，衛星を利用する場合のテレビ伝送標準に関 し次のような決定を行なった20).

（1）白黒テレビの伝送は，走査線数 525 本/フィー ルド周波数 $60 \mathrm{~Hz}$ の方式抒よび 625 本 $/ 50 \mathrm{~Hz}$ の方式之
する.

（2）カラーテレビ信号の伝送では，上記のいずれか の走查標準において NTSC, PAL または SECAM 方式 とする.

（3）衛星回線区間の伝送整準は, 原則として送信㑡 の標準による.したがって, 受信側で必要な方式变換を 行なう.

（4）いずれの標準によるかは各地球局所有者の責任 において決定することができる.

地球局のテレビ伝送設備は, 上記の各項目を前提とし て設計されているすのの，すべての地球局がこれらの条 件を満足するには至っていない，表 3 は現在, 茨城求よ び山口地球局がテレビ回線を開設している相手地球局の 設備状況を示すむのである ${ }^{21)}$ ，な打山口地球局はヨーロ ッパとのテレビ伝送を考慮して各種の設備が用意されて いるが222，最近テレビ標準方式変換装置を設置したとと により，前述の条件を $100 \%$ 満足できるようになった.

1970〜1971 年にかけて実施されたテレビ関係の整備 としては，茨城地球局（第 2 施設）に拈けるテレビ同時 2 伝送のための設備と，NTT による国内回線区間の映 音同時伝送システムの採用に伴う関連設備の増設などが

表 3 太平洋およびインド洋衛星地域の地球局のテレビ伝送設備の現状 (1971 年 12 月 31 日現在)

\begin{tabular}{|c|c|c|c|c|c|c|c|c|c|c|c|c|c|c|c|c|c|c|c|c|c|c|c|c|}
\hline \multicolumn{3}{|c|}{ 人 $\quad$ 衛星地域 } & \multicolumn{12}{|c|}{ 太平洋衛星地域 } & \multicolumn{10}{|c|}{ インド洋衛星地域 } \\
\hline \multirow{3}{*}{\multicolumn{3}{|c|}{ テレビ標準方式 }} & 日 & & 米 & 国 & & オ & 7 & 中 & 香 & 夕 & $=H^{\prime}$ & 韓 & 日 & 英 & 西 & 1 & 1 & $\eta$ & $\nabla$ & z & シ & \& \\
\hline & & & 本 & $\mid \begin{array}{l}\text { 本 } \\
\text { 土 }\end{array}$ & $\begin{array}{l}\text { 八 } \\
7 \\
1\end{array}$ & $\begin{array}{l}\text { グ } \\
\supset \\
\text { ム }\end{array}$ & $\begin{array}{l}\text { ア } \\
\bar{j} \\
\text { ス } \\
\text { カ }\end{array}$ & $\begin{array}{l}2 \\
1 \\
5 \\
1 \\
j \\
\end{array}$ & $\begin{array}{l}1 \\
\% \\
ヒ^{\circ} \\
y\end{array}$ & $\begin{array}{l}\text { 華 } \\
\text { 民 } \\
\text { 国 }\end{array}$ & 港 & 1 & $\begin{array}{l}1 \\
\vdots \\
1 \\
5 \\
y \\
y \\
\end{array}$ & 国 & 本 & 国 & $\begin{array}{l}\text { ド } \\
1 \\
\text { \% }\end{array}$ & $\begin{array}{l}k \\
\text { ネ } \\
\text { シ } \\
\text { ア }\end{array}$ & $\begin{array}{l}\text { 夕 } \\
\text { リ } \\
1\end{array}$ & $\begin{array}{l}n \\
x \\
1 \\
1\end{array}$ & $\begin{array}{l}2 \\
1 \\
\text { シ } \\
3\end{array}$ & $\begin{array}{l}\text { ペ } \\
1 \\
\text { ン }\end{array}$ & $\begin{array}{c}\text { ガ } \\
\text { ポ } \\
1 \\
\text { ル }\end{array}$ & 1 \\
\hline & & & $\begin{array}{l}\text { 茨 } \\
\text { 城 } \\
\text { 第 } \\
\sqrt[3]{-}\end{array}$ & 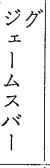 & 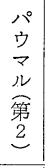 & $\begin{array}{l}70 \\
5 \\
2 \\
\text { 夕 } \\
\text { \% } \\
1\end{array}$ & $\begin{array}{l}\text { バ } \\
1 \\
\text { ト } \\
\text { レ } \\
\% \\
\text { ト }\end{array}$ & $\begin{array}{l}モ \\
\text { リ } \\
1\end{array}$ & 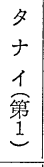 & $\begin{array}{l}\text { 台 } \\
\text { 北 }\end{array}$ & $\begin{array}{l}\text { 香 } \\
\\
\text { 港 } \\
\text { 第 } \\
\text { 年 } \\
\end{array}$ & $\begin{array}{l}\text { シ } \\
\text { 亏 } \\
\text { チ } \\
+ \\
\text { 第 } \\
\text { 1 }\end{array}$ & $\left|\begin{array}{c}n \\
才 \\
1 \\
n \\
\eta \\
1 \\
1 \\
\text { ス }\end{array}\right|$ & 錦 & 山 & 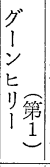 & 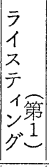 & $\begin{array}{l}シ \\
+ \\
f \\
ル \\
ハ\end{array}$ & \begin{tabular}{c}
$>$ \\
f \\
\multicolumn{2}{c}{} \\
第 \\
$己$
\end{tabular} & $\begin{array}{l}\dot{D} \\
厶 \\
\dot{\vec{p}} \\
\mu \\
\dot{\vec{p}} \\
\dot{\nu}\end{array}$ & $\begin{array}{c}y \\
> \\
2 \\
y \\
2\end{array}$ & $\mid \begin{array}{l}\mid 7 \\
1 \\
1 \\
1 \\
\exists \\
\exists \text { 第 } \\
2 \\
\end{array}$ & $\left|\begin{array}{c}セ \\
v \\
r \\
+\end{array}\right|$ & $\begin{array}{l}\text { シ } \\
\text { 亏 } \\
\text { F } \\
\stackrel{2}{+} \\
\text { 第 } \\
2 \\
\end{array}$ \\
\hline \multirow{2}{*}{\begin{tabular}{l|} 
送 \\
信 \\
設 \\
備
\end{tabular}} & 皇 & $\begin{array}{l}525 / 60 \\
625 / 50 \\
\end{array}$ & $\begin{array}{l}0 \\
0 \\
\end{array}$ & 0 & 0 & 0 & $\bigcirc$ & $\begin{array}{l}0 \\
0 \\
\end{array}$ & 0 & 0 & $\begin{array}{l}0 \\
0 \\
\end{array}$ & 0 & $\begin{array}{l}0 \\
0\end{array}$ & 0 & $\begin{array}{l}0 \\
0\end{array}$ & $\begin{array}{l}0 \\
0\end{array}$ & $\begin{array}{l}0 \\
0 \\
\end{array}$ & 0 & $\begin{array}{l}0 \\
0 \\
\end{array}$ & 0 & 0 & $\begin{array}{l}0 \\
0 \\
\end{array}$ & 0 & 0 \\
\hline & $\begin{array}{l}\text { 力 } \\
\text { ज } \\
1\end{array}$ & $\begin{array}{l}\text { 525/60 NTSC } \\
\text { 625/50 PAL } \\
625 / 50 \text { SECAM }\end{array}$ & $\begin{array}{l}0 \\
0\end{array}$ & 0 & 0 & $\mathrm{O}$ & 0 & 0 & 0 & 0 & $\begin{array}{l}0 \\
0\end{array}$ & & $\begin{array}{l}0 \\
0\end{array}$ & $\mathrm{P}$ & $\begin{array}{l}0 \\
0 \\
0\end{array}$ & $\begin{array}{l}0 \\
0\end{array}$ & $\begin{array}{l}0 \\
0\end{array}$ & & $\begin{array}{l}0 \\
0\end{array}$ & & & 0 & 0 & \\
\hline \multirow{2}{*}{$\begin{array}{l}\text { 受 } \\
\text { 信 } \\
\text { 設 } \\
\text { 備 }\end{array}$} & 皇 & $\begin{array}{l}525 / 60 \\
625 / 50 \\
\end{array}$ & $\begin{array}{l}0 \\
0\end{array}$ & 0 & 0 & 0 & O & $\begin{array}{l}0 \\
0 \\
\end{array}$ & 0 & 0 & $\begin{array}{l}0 \\
0\end{array}$ & 0 & $\begin{array}{l}0 \\
0\end{array}$ & 0 & $\begin{array}{l}0 \\
0\end{array}$ & $\left|\begin{array}{l}0 \\
0\end{array}\right|$ & $\left|\begin{array}{l}0 \\
0\end{array}\right|$ & 0 & $\begin{array}{l}0 \\
0\end{array}$ & $\begin{array}{l}0 \\
0\end{array}$ & 0 & $\begin{array}{l}0 \\
0\end{array}$ & & 0 \\
\hline & $\begin{array}{l}\text { 力 } \\
\bar{j} \\
1\end{array}$ & $\begin{array}{l}525 / 60 \text { NTSC } \\
625 / 50 \text { PAL } \\
625 / 50 \text { SECAM }\end{array}$ & $\begin{array}{l}0 \\
0\end{array}$ & 0 & 0 & 0 & 0 & 0 & 0 & 0 & $\begin{array}{l}0 \\
0\end{array}$ & & $\begin{array}{l}0 \\
0\end{array}$ & $\mathrm{P}$ & $\begin{array}{l}0 \\
0 \\
0\end{array}$ & $\begin{array}{l}0 \\
0\end{array}$ & $\begin{array}{l}0 \\
0 \\
0\end{array}$ & & $\begin{array}{l}0 \\
0\end{array}$ & 0 & & 0 & 0 & \\
\hline \multirow[b]{2}{*}{$\begin{array}{l}\text { 方 } \\
\text { 式 } \\
\text { 変 } \\
\text { 換 } \\
\text { 設 } \\
\text { 備 }\end{array}$} & 皇 & $\begin{array}{l}525 / 60 \rightarrow 625 / 50 \\
625 / 50 \rightarrow 525 / 60\end{array}$ & & & & & & & & & & & $\begin{array}{l}0 \\
0 \\
\end{array}$ & & $\begin{array}{l}0 \\
0\end{array}$ & \begin{tabular}{|l|}
$\bigcirc^{*}$ \\
$O^{*}$ \\
\end{tabular} & $\begin{array}{l}0 \\
0\end{array}$ & & $\begin{array}{l}0 \\
0 \\
\end{array}$ & 0 & & $\begin{array}{l}0 \\
0\end{array}$ & & \\
\hline & 1 & $\begin{array}{l}525 / 60 \mathrm{NTSC} \rightarrow 625 / 50 \mathrm{PAL} \\
525 / 60 \mathrm{NTSC} \rightarrow 625 / 50 \mathrm{SECAM} \\
625 / 50 \mathrm{PAL} \rightarrow 525 / 60 \mathrm{NTSC} \\
625 / 50 \mathrm{SECAM} \rightarrow 525 / 60 \mathrm{NTSC} \\
625 / 50 \mathrm{PAL} \rightarrow 625 / 50 \mathrm{SECAM} \\
625 / 50 \mathrm{SECAM} \rightarrow 625 / 50 \mathrm{PAL}\end{array}$ & & & & & & & & & & & $\begin{array}{l}0 \\
0\end{array}$ & & $\begin{array}{l}0 \\
0 \\
0 \\
0 \\
0 \\
0\end{array}$ & $\begin{array}{l}\text { O* } \\
\text { O* } \\
\text { O* }\end{array}$ & $\begin{array}{l}0 \\
0\end{array}$ & & $\begin{array}{l}0 \\
0\end{array}$ & & & 0 & & \\
\hline
\end{tabular}

$\mathrm{P}:$ 計画中 $\quad *$ : 標準方式の変換は BBC または ITN で行なう. 
ある. また, 山口地球局では, 1969 年に引き続き設計, 製作を進めていた，テレビ標準方式変換装置が完成し， 1971 年 3 月据付けを完了した. この他，625 ライン方式 のカラーテレビ用測定装置の増設，およびインド洋上の III 号 $(\mathrm{F}-3)$ 衛星の B トランスポンダー利得低下をカバ 一するためテレビ用送信電波 $(6390 \mathrm{MHz})$ の増力対策 を実施した ${ }^{23)}$.

外国地球局設備で注目されることは,ライスティング, フチノおよびブイトラゴ地球局に最新形の再撮像方式に よる標準方式変換装置が, ウォークワース地球局に全電 子式変換装置がそれぞれ設置され，変換業務を行なって いるととである.

\section{2 茨城衛星通信所第 3 施設の完成}

茨城第 3 施設は, ICSC が定めた INTELSAT-IV 号 系衛星のための標準地球局特性を満足する地球局として 世界で最初に建設され，1971 年 8 月末に完成した。 との 施設は 9 月 13 日 INTELSAT の性能確認試験 (Verification test) をすませ, III 拉よび IV 号系衛星にアクセ スするための技術的条件が整っているととが確認され た.

この施設については，文献 24）に詳述されているが, テレビ伝送用設備に限れば，次のような特徴を有してい る.

（1）大電力増幅器として，従来クライストロンを用 いたテレビ搬送波専用の増幅器を使用してきたが，大電 力用 $\mathrm{TWT}$ (飽和出力 $8 \mathrm{~kW}$ ) の開発により 1 台の TWT 増幅器でテレビおよび電話の搬送波を共通増幅できる.

（2）テレビ用搬送波の送受容量増が容易に行なえる よう，合成および分岐回路に余裕を持たせてある.

（3）テレビ同時 2 伝送のための送信および受信が可 能な映像および音声設備が用意されている（無線系の第 2 ルート本設備は 1972 年 11 月に完成の予定).

(4) 525 ラインNTSC 方式はむとより，625 ライン PAL 方式のテレビ信号を伝送するための監視および試 験装置が用意されている。

茨城第 3 施設は, 現在太平洋の INTELSAT-IV 号 (F-4) 衛星にアクセスしているが, 運用パラメーターの 主要なものはすでに表 2 に示したと抢りである.

\section{3 テレビ標準方式変換装置}

テレビ標準方式変換の技術は，日本，英国执よび西ド イッにおけるカラーテレビ信号のための変換装置の実用 化により一応の完成をみたといえよう.

わが国では，NHK が開発し，会館運用センター (TOC) に設置した装置を白黒テレビ用からカラーテレ ビ用に改修し ${ }^{25)}$ ，さらに non-fixed-ratio の変換が可能 なように改良を行なった ${ }^{26)}$.とれは 525 ラインNTSC 方
式のカラーテレビ信号のフィールド周波数が $59.94 \mathrm{~Hz}$, 625 ラインPAL あるいは SECAM 方式では $50 \mathrm{~Hz}$ であ り，画者の間に整数比の関係が成り立たないため，白黒 テレビ信号の変換に用いられた同期追従方式とは異なる 同期独立変換方式（ノンロック方式とあいう）を採用す る必要があったためである，TOC の変換装置は，現在 主として, テープ番組交換のための変換に利用されてい $ろ^{27)}$.

一方, 1969 年 KDD は衛星中継回線用の標準方式変換 装置の開発に着手し, 1971 年 3 月完成した実用機を山口 地球局に設置した ${ }^{28)}$.

この装置は，4.1 節で述べた衛星回線のテレビ伝送標 準の条件に合致するとともに，発展途上国とのテレビ伝 送や 2 ホップの衛星回線区間で構成される回線による中 継のための変換をむ考慮して設計された. すなわち，乙 の装置により 625 ライン方式の白黒信号から 525 ライン 方式の白黒信号への変換と, その逆変換, 625 ラインPAL あるいは SECAM 方式の信号から 525 ライン NTSC 方式の信号へのカラーテレビ信号の変換と, その逆変換 ならびに 625 ライン PAL および SECAM 方式の信号 間のカラートランスコーディングが可能である. 変換装 置は入力および出力信号にそれぞれ設定された時間基準 点の差を計測し，その情報により㸕延線を切り替えるこ とによって, 入力信号の同期とはまったく独立の標準出 力同期信号で制御された変換出力信号を得る，いわゆる “同期独立変換方式”を用いている. また， $4.5 \mathrm{MHz}$ の 色副搬送波を色差信号で直角振幅変調して得られた中間 映像信号を採用して走査標準変換系の構成を簡素化し た.との装置を実現するために開発された新技術は次の とおりである.

（1）同期独立変換のための実時間計測による時間差 予测方式と時間差計測方式 ${ }^{29)}$.

(2) $31 \mathrm{MHz}$ 帯域用精密時間誤差補正器 (TEC) と TEC の制御に必要な高精度時間長測定方式 ${ }^{30)}$.

（3）中間映像信号用エンコーダー，デコーダーおよ び $4.5 \mathrm{MHz}$ 色副搬送波発生方式 ${ }^{31)}$.

（4）最適な変換単位 $(66.333 \mu \mathrm{s})$ の選定と新しい変 換系の構成 ${ }^{32)}$.

（5）超音波水晶遅延線素子のための振幅执よび遅延 特性の等化 ${ }^{33)}$.

外国の例では， $\mathrm{BBC}$ の開発によるラインストアコン バーターと遲延線切り替え方式のフィールドコンバータ 一を用いた変換装置を基本にして, 英国の製造会社が, 全系を遅延線切り替え方式に統一した変換装置を完成し た ${ }^{34)}$. この装置はITN (ロンドン), ウォークワース地 球局などに設置され商用に供されている. 最近, テレビ 
信号をアナログ情報のまま変換するこれまでの手法にと って代る新しいディジタル処理の研究がなされており， PCM 技術を用いた走査線変換装置が ITN および BBC により発表された ${ }^{35)}$ 36). との装置はシフトレジスター形 の 1 走査線メモリーを 3 組使用して, 625 ライン方式と 405 ライン方式間の変換を行なっている.

西ドイッで開発された再撮像方式によるカラーテレビ 用変換装置は, その後, 特性の改善が行なわれ, 高品質 のカラー変換画像が得られている ${ }^{36)}$. この装置はパリの ORTF，ライスティング，フチノおよびブィトラゴ地球 局などで使用されている.

\subsection{KDD の国際テレビセンター (ITC) 設備 ${ }^{23)}$}

国際テレビ回線のための統制局である ITC は，乙れ までの設備を整備し，同一時間帯におけるテレビ同時 2 伝送に対処できるようにした．また，衛星回線区間の輻 輳あるいは障害によって起こる茨城・山口両地球局経由 の 2 ホップテレビ伝送や，山口局の方式変換装置の有効 利用を考えて，625 ライン PAL 方式の信号の伝送が可 能なように映像調整装置扣よびカラーモニターを新設し た.

\section{5 国内連絡線設備 ${ }^{23)}$}

国際テレビ回線のうち，ITC と地球局を結ぶ国内回線 区間は, 現在 NTT の回線を利用している. NTTはこ の国内回線のうちマイクロルートについて, 1970 年 11 月から映像・音声同時伝送方式をとるとととなったので これに伴う対応整備として, 茨城地球局でテレビ関係設 備の整備が実施された.

\section{5. 通信衛星技術の動向}

\section{$5.1 \mathrm{CCIR}$ 特別合同会議 $(\mathrm{SJM})^{38)}$ および宇宙通信の ための世界主管庁会議 (WARC-ST) ${ }^{39)}$}

1971 年 $2 \sim 3$ 月に開催された CCIR-SJM は, 同年 6 〜 月の WARC-ST に执いて必要とする技術的な基礎 を固めるととを任務とする特別な会議で，8つの作業部 会で宇宙通信全般に及ぶ審議を行なった．テレビ伝送に 関するあのとして, 衛星通信のための周波数選定, 衛星 に許容される最大電力束密度, 地球局に許容される最大 e. i. r. p., 地球局アンテナの最小運用仰角などの審議が行 なわれた。 また, 衛星放送のための最適周波数帯と帯域 幅, 受信品質, 変調方式, 混信保護比, 周波数共用など に関する審議が行なわれた。

WARC-ST は SJM の結果をもとに審議を行ない, 無線通信規則の修正作業を行ない，最終文書が採択され た.

\subsection{INTELSAT 以外の通信衛星系}

MOLNYA-1号衛星による国内衛星通信システムとし
て完成されたソ連の ORBITA 網は，モンゴル共和国の 参加により国際配給衛星システムとして利用されるよう になった. MOLNYA-1 号衛星は 17 個の打上げに成功 し (1970 年末現在)，乙れらの衛星を利用してソ連中央 テレビサービスの番組を受信できる局は 35 局となっ た ${ }^{13)}$. この ORBITA 網を基盤にして, 1971 年 11 月ソ 連はモスクワで，ブルガリア，ハンガリー，ポーラン ド, ルーマニア，東ドイッ，チェコスロバキャ，モンゴ ル，キューバの社会主義 8 力国ととあに, INTERSPUTNIK を設立する協定に署名した ${ }^{40)}$.

一方，ヨーロッパ郵便・通信主管庁会議 (CEPT) は, INTELSAT のヨーロッパ版ともいえるヨーロッパ通信 衛星機構 (EUTELSAT) 設立の構想を発表した ${ }^{41)}$. この 組織は CEPT 加盟国に対し，ヨーロッパ内の電話，電 報, テレックス, データ通信業務, ならびに EUROVISION のテレビ番組の伝送を行なうあので，運用は 1980 〜1990年を予定している. このシステムの特徴として, 3 軸安定方式による衛星の使用, $10 \mathrm{GHz}$ 以上の周波数 の利用，新技術の大幅な採用などがあげられる.

\section{3 通信衛星計画の現状}

国内通信衛星システム開発のための研究として, 日本, 米国およびカナダにみられる国内通信衛星計画, カナダ の国内衛星に続く，通信技術衛星 (CTS) 計画などがあ る $^{13) 42) 43)}$.

米国航空宇宙局 (NASA) が打上げた ATS を利用し て行なわれる実験には, 米国に限らず広く世界各国が参 加している. わが国は郵政省鹿島地球局が，1970年鹿島 局の通信可能範囲にある ATS-I 号を用いて, NHK が 開発したテレビ音声信号を色同期情報を利用して伝送す る PCM-テレビ音声同時伝送方式の実験を行ない，満足 すべき結果が得られた ${ }^{44)}$. NASA の今後の計画による と，1973 年初めに ATS-F を打上げ，米国はむちろん ブラジルおよびインドがこの衛星を利用して教育テレビ 放送の実験を行なうととになっている(5).

\section{4 放送衛星 ${ }^{45)}$}

放送衛星の経済的および技術的検討は，前述のWAR C-ST，CCIR，国連宇宙空間平和利用委員会，EBU な らびにアジア放送連盟 $(\mathrm{ABU})$ で行なわれている. 特に, 1971 年に開催された WARC-ST に掠いて放送衛星用 の周波数の割当てが行なわれたととにより，放送衛星シ ステム実用化のための研究は一段と前進するあのと期待 される.

テレビ放送衛星の当面の実験予定としては, NASA が 主体となるATS による実験放送計画, Telesat Canada 会社が行なう番組分配衛星 (Anik 1)，ヨーロッパにおけ る番組分配衛星計画，ABUSAT 計画，インドの放送衛 
星計画などがある.なお、インドは ATS-F による実験 に引き続いて，UHF 帯で 4 チャネルのテレビと 3,600 チャネルの電話伝送容量を持つ放送・通信衛星 (INSAT) を打上げる計画を明らかにしている。

\section{6. むす び}

この 2 年間に，国際テレビ中継回線は INTELSAT 衛 星システムの拡充に伴い, 著しく增強された. 特に, こ れまでの世界通信網用 INTELSAT-III 号系衛星は, イ ンド洋地域を除き IV 号系衛星に置き換えられ, 回線特 性の向上, 安定化, 回線増対策などがはかられた。ささら に，IV 号系认続くV 号系衛星の研究，開発がすでに 始められている.

一方, 長距離国際テレビ回線全般としては, 標準擬似 チェーン抢よび伝送特性の研究, 既設国内回線区間の特 性向上など，解決を要する問題が残されているととを見 逃すわけには行かない。また，INTELSAT 網と他の衛 星通信網とを接続するための国際協調も重要な課題とい えよう.

放送衛星は，当初の見込みよりその実現が遅れてきて いるが，実験開始も目前であり，いっそうの技術的進歩 が期待される.

なお，テレビ番組に付帯する音声信号の伝送について は, 紙面の都合で一部割愛させていただいたととを抗と とわりする，また，技術的な詳細については，巻末の文 献を参照されたい.

\section{〔参考 文 献〕}

1) CCIR Rec. 421-2, New Delhi, 1970

2) CCITT Contribution COM IV-No. 110, 1968-1972

3) INTELSAT SSOG, Vol. II, June, 1971

4) CCIR Rep. 487, New Delhi, 1970

5) 室谷: CCIR 最終会議, 総会報告 (CMTT), テレビ学会伝送委 資料, 19-2 (1970)

6) 佐藤: CCITT SG IV テレビション專門家会議報告, 国際通信 の研究, 72 (1972) 101

7) Single video-frequency noise weighting, 電波技術審議会第 1 部 会資料, 1-0-45 (1971)

8) Comments on the insertion of special signals in the field-blanking interval of a television signal in 525-line system for international transmission, 電波技術審議会第 1 部会資料, 1-0-46 (1971)

9) Transmission of sound and vision signals by time-division multiplex-A time division multiplex transmission system for television sound using a common colour sync signal, 電波技 術審議会第 1 部会資料, 1-0-48 (1971)
10) 宮編：衛星通信工学, 丸善 (1969)

11) Performance characteristics of earth stations in the INTELSAT IV system, ICSC-45-13 E (1970)

12) KDD 編: 国際通信統計月啹, 各号

13）郵政省, $\mathrm{KDD}$ 編：衛星通偪年報(昭和45年度), 第皿部 (1971)

14）二階堂, 緒方, 桜田：第 6 回アジア競技大会中継，放送技術，24, 3 (1971) 124

15) 石村：双方向伝送による二つの衛星中継，放送技術，24，8(1971) 86

16）注目あびるテレビ電話実験，国際電信電話，19，6 (1971) 17

17) ニュース，テレビ誌，25，7 (1971) 587

18）天皇・皇后両陛下ご訪欧テレビ衛星中継(度談会)，放送技術，25, 1 (1972) 59

19）副島：札棍オリンピック大会放送の概要，放送技術，25，2(1972) 59

20）郵政省，KDD 編：衛星通信年報(昭和45年度)，第部 (1971)

21) INTELSAT Operational Information Memorandum, No. 3 (1971)

22）冨田, 佐藤: 衛星中継 T V 回線用設借とその特性, テレビ学会伝 送委資料，21-2 (1970)

23）郵政省, KDD 編：衛星通信年報（昭和45年度)，第 I 部 (1971)

24) 伝送施設部, 建築部, 茨城衛星通信所: 茨城衛星通信所第 3 施設 の概要, 国際通信の研究, 72 (1972) 1

25）日下，谷村：放送会館で運用に入ったカラー方式変換装置, NHK 技研月報, 12, 11 (1969)

26)坂田ほか：テレビジョン標準方式変換装稙特集，NHK 技術研究， 23, 3 (1971) 161

27) Proposed amendments to Report 311-1 "The present position of standards conversion”, 電波技術審議会第 1 部会資料, 1-044 (1971)

28）たとえば, 佐藤, 衣畑, 巻田: テレビ標準方式変換装置, 国際通 信の研究, 69 (1971) 1

29）佐藤ほか：TSC の制御方式, テレビ全大子，2-4 (1971) 33

30）佐藤ほか：TSCの FM 時間訹差補正方式, テレビ全大予, 2-5 (1971) 35

31) 佐藤ほか：TSCの中間映像信号形式, テレビ全大予, 2-2(1971) 29

32）佐藤ほか：TSC の走査方式変換系，テレビ全大予，2-3 (1971) 31

33）佐藤ほか：TSCに用いた遅姃線について，テレビ全大予，2-6 (1971) 37

34) Field store television standards converter, Rank Precision Industries Ltd. カタログ

35) ニュース, テレビ誌, 25, 10 (1971) 849

36) Lord, A. V, Rainger, P. and Rout, E. R.: Digital line store standards conversion, IEE Conference Publication, No. 69

37) Farb-Normwandler, Fernseh-Studiogerate カタログ N 40-1 (1970)

38）たとえば，新川ほか：CCIR 特別合同研究委員会会議報告, 国際 通信の研究, 70 (1971) 29

39）たとえば, 有竹ほか：衛星通信世界然線主管圢会議報告, 国際通 信の研究, 70 (1971) 83

40) AIR \& COSMOS, Nov. 20, 1971

41) Technishce Mitteilungen PTT-News Digest, 15, 32, 11

42) 加藤：わが国の宇宙開発計画とその現状, 電波時報, 27, 1(1972) 26

43）カナダの通信技術衛星について，テレビ学会伝送委資料，31-3 (1972)

44）たとえば, 今井ほか：ATS-1 による PCM-TV 音声伝送実験に ついて，テレビ学会伝送委凟料，23-1 (1970)

45）泉：衛星放送の最近の動向, テレビ誌，25，5 (1971) 365 